\title{
IgG and IgM antibodies to viral glycoproteins in respiratory syncytial virus infections of graded severity
}

\author{
G L TOMS, ${ }^{*}$ M S C WEBB, $\dagger$ P D MILNER, ${ }^{*}$ A D MILNER, $\dagger$ E G ROUTLEDGE, ${ }^{*} \mathrm{R}$ SCOTT, ${ }^{*}$ \\ G M STOKES,, A SWARBRICK, $\dagger$ AND C E TAYLOR* \\ ${ }^{*}$ Department of Virology, University of Newcastle upon Tyne, and †Department of Child Health, University \\ of Nottingham
}

SUMmARY Serum antibodies to the fusion (F) and large glycoprotein (G) of respiratory syncytial virus in the serum of 57 infected infants were measured by enzyme linked immunosorbent assay (ELISA). Most serum samples taken at the time of admission to hospital contained antibodies to both glycoproteins, and overall there was no significant evidence of a selective deficiency of antibody to either viral antigen. Less than a quarter of the infants showed rising IgG antibody titres to either glycoprotein after infection, whereas over threequarters produced an IgM response. There was a significant correlation between IgG response to viral glycoproteins and the age of the infant. The correlation of age with the IgM response was less pronounced, and there was no correlation between serum IgG antibody derived transplacentally in the acute phase of infection and IgM response to either glycoprotein. Neither IgG or IgM responses correlated with a clinical assessment of the severity of infection in the infants. IgM responses, however, were weakly correlated with reduced secretion of infectious virus in the upper respiratory tract.

Bronchiolitis after respiratory syncytial virus infection is most prevalent in the first six months of life when concentrations of transplacentally acquired antibody to the virus in infant serum samples are high. ${ }^{1}$ The beneficial effect of passively acquired maternal antibody is uncertain. In animals, passive administration of antibody before infection is protective $^{2}$ and, in preliminary experimental studies in human infants, treatment with immune globulin has proved to be beneficial. ${ }^{3}$ Commensurate with these findings bronchiolitis is rare in the first month of life when antibody titres acquired transplacentally are high, ${ }^{4}$ and epidemiological studies indicate that infants whose mothers have the highest concentrations of serum antibody at birth are protected for longer. ${ }^{56}$

Nevertheless, for infants admitted to hospital with bronchiolitis, maternal antibody must have been inadequate to control their infection, although it is often present at reasonable concentrations. In these infants serum IgG antibody responses to the virus are low and frequently undetectable ${ }^{7}$ although most infants mount a local $\operatorname{IgA}$ antibody response. ${ }^{8}$ It is possible that IgG antibody in the serum acquired transplacentally merely masks the development of the infant IgG response but it has been suggested that maternal antibody may also be immunosuppressive.

Respiratory syncytial virus bears two glycoproteins upon its surface-the $G$ glycoprotein that is responsible for virion attachment to susceptible cells and the $\mathrm{F}$ or fusion glycoprotein that mediates fusion of virion and cellular membranes and thus intracellular penetration of the virus. ${ }^{910}$ Antibodies to both glycoproteins can neutralise the virus and immunisation with these (but not internal virion proteins) is protective in animals. ${ }^{11}$ The $\mathrm{F}$ glycoprotein seems to generate more effective immunogenic responses. Antigenic variation in the $\mathrm{G}$ glycoprotein has been reported between isolates of respiratory syncytial virus, although the $F$ glycoprotein seems remarkably stable. This suggests that in humans the $\mathrm{G}$ protein is an important protective antigen and subject to selective pressure by the immune response. ${ }^{1213}$ Murphy et al have reported that the immunosuppressive effect of antibody acquired transplacentally is most pronounced on the antibody response to the $G$ glycoprotein of the virus. ${ }^{14}$ In 
other studies anti-G antibody concentrations have been found to be low or absent in serum samples from infants with bronchiolitis, and it has been suggested that susceptibility to the virus may result from an inability to respond to the $G$ glycoprotein. ${ }^{15} 16$

We have recently purified the two glycoproteins of a subgroup A strain of respiratory syncytial virus. ${ }^{11}$ In the present study we have used immunoglobulin class specific enzyme linked immunosorbent assays (ELISA) for antibodies to these proteins to compare the IgG and IgM antibody responses to $G$ and $F$ glycoproteins in a group of infants admitted to hospital with respiratory syncytial virus infection, and to assess the inhibitory effect of antibody acquired transplacentally on these responses. In addition we have investigated correlations between antibody responses, viral titres in the upper respiratory tract, and the clinical severity of infection to assess the importance of each glycoprotein specific antibody in protection.

\section{Patients and methods}

Fifty seven infants between 3 and 40 weeks of age admitted to the Queen's Medical Centre, Nottingham between January and March 1984 with respiratory syncytial virus infection were subjected to intensive clinical and virological assessment described in detail elsewhere (C E Taylor, unpublished observations). Briefly, infection was diagnosed by immunofluorescence, severity of infection was assessed by daily examination resulting in a severity score at discharge from hospital, and nasopharyngeal secretions were taken daily and titrated for infectious virus by an infectious focus assay.

Blood samples were collected by venepuncture on admission and about 10 weeks later (mean (SD) 67 (17) days), frozen immediately in liquid nitrogen, and stored at $-70^{\circ} \mathrm{C}$ until thawed for assay.

\section{ELISA FOR ANTIBODIES TO RESPIRATORY SYNCYTIAL} VIRUS GLYCOPROTEINS F AND G

Immunoaffinity purified respiratory syncytial virus fusion glycoprotein (F) and large glycoprotein (G) were prepared as previously described. ${ }^{11}$ Samples of human serum were titrated for antibody against each protein by ELISA as described by Voller $e t$ al. ${ }^{17}$ Briefly, Dynatech 129A microtitre plates were coated overnight with $33 \mu \mathrm{g} / \mathrm{ml}$ of $\mathrm{F}$, or $60 \mu \mathrm{g} / \mathrm{ml}$ of $\mathrm{G}$, glycoprotein in bicarbonate buffer at $\mathrm{pH} 9 \cdot 6$. After washing in phosphate buffered saline containing $0.5 \%$ Tween 20 (Sigma) the plates were loaded with $50 \mu \mathrm{l} /$ well of serum diluent and each sample was diluted in fourfold steps. For IgM assays a protein extract of HeLa cells prepared as described by Nan- dapalan $e$ al was included in the conjugate diluent at a final concentration of $10 \%$ to reduce non-specific binding. ${ }^{18}$ After incubation for 90 minutes at $37^{\circ} \mathrm{C}$ to allow adsorption, the binding of IgG was detected with peroxidase conjugated rabbit immunoglobulins to human IgG ( $\gamma$ chains) or to human IgM ( $\mu$ chains), as appropriate. The binding of conjugate was determined by standard methods using orthophenylene diamine as a substrate.

Titres for samples were determined by comparison with a standard serum pool in each plate. Differences in titre between test and standard serum assays were determined on the straight line portion of their curves and the difference in titre was added to the known titre of the standard serum previously determined as the mean of the reciprocal of the dilution giving an optical density of 1.0 in repeated assays. An optical density of $0 \cdot 2$ above serum free, capture plus conjugate, control wells was arbitrarily taken as the cut off between positivity and negativity in all assays. As the sensitivity of assays for different immunoglobulins varied the cut off corresponded to a different minimum detectable titre in each case. In the 5-10 plates used for each assay type the cut off corresponded to a $\log _{10}$ titre of $1 \cdot 1(0 \cdot 5), 1 \cdot 6(0 \cdot 7)$, $0.8(0.4)$, and $0.76(0.4)$ for IgG anti-F and G glycoprotein, and IgM anti-F and $G$ glycoprotein assays, respectively. For statistical analyses negative results were taken as $0 \cdot 1$ below the $\log _{10}$ cut off value for the given plate. In each plate an aliquot of a second serum pool was titrated to give an estimate of the reproducibility of the assay. In over 10 assays of each type the results for this serum were mean (SD) $\log _{10} 3.0(0.3), 2.9(0.23), 1.5(0.36)$, and 1.82 $(0.32)$ for IgG anti-F and $\mathrm{G}$ glycoprotein, and IgM anti-F and $G$ glycoprotein assays, respectively.

As a check on specificity ascites fluids containing mouse monoclonal antibodies to the $F$ and $G$ glycoproteins and to the viral nucleoprotein, matrix protein, phosphoprotein, and $22 \mathrm{~K}$ protein, were titrated on $F$ and $G$ glycoprotein coated plates using a rabbit antimouse immunoglobulin peroxidase conjugate (ICN Biomedicals). With the F glycoprotein as antigen, the anti-F glycoprotein monoclonal antibody gave a titre of $>1 / 640000$, the anti-22K protein monoclonal antibody gave a titre of $1 / 199$, and all the others were negative at $1 / 100$. With the $G$ glycoprotein as antigen, and anti-G monoclonal antibody gave a titre of $1 / 640000$ but all the others were negative at $1 / 100$.

\section{ASSAY FOR RHEUMATOID FACTOR}

Rheumatoid factor in serum samples was estimated in an assay similar to that for specific IgM antibody except that the plates were coated with $10 \mu \mathrm{g} / \mathrm{ml}$ of affinity purified human IgG instead of respiratory 
syncytial virus glycoprotein, and samples were diluted in diluent that did not contain HeLa cell extract. Titres were calculated in the same way as for specific antibody using the same serum standards which both contained low levels of rheumatoid factor. The assay was standardised by titration of five positive control serum samples. The effective limit of detection of the test was $0 \cdot 14$ IU of rheumatoid factor in $16 \mu \mathrm{l}$ of serum. The mean (SD) reproducibility of 12 independent assays made on frozen aliquots of a known postive serum was $1.78(0.54) \mathrm{IU} /$ $\mathrm{ml}$.

\section{STATISTICAL ANALYSIS}

When variables were normally distributed comparisons were made and correlation coefficients derived by least squares linear regression. Where one of the variables was not normally distributed and correlations seemed significant the variables were also tested by Spearman's rank test.

\section{Results}

More infants possessed IgG antibody to the $\mathrm{F}$ protein than to the $G$ protein at the acute stage of infection (table 1). Mean titres of antibody to the $F$ protein were slightly higher than those to the $G$ protein. Although overall there was no significant rise in mean antibody to either protein between acute and convalescent samples, individuals did show rises not accountable for by assay variability. The log increment in IgG antibody to both $\mathrm{F}$ and $\mathrm{G}$ glycoproteins was normally distributed. Twice as many infants mounted a rise in antibody against the $\mathrm{F}$ protein as against $G$. This difference was not significant $\left(\chi^{2}\right.$ test).

IgM antibodies to both proteins were detected in the serum samples of most infants at the time of admission to hospital. In only a few was there a further increase on testing two to three months later. This is consistent with the transient nature of the IgM response, peak titres being expected at three to four weeks after infection. ${ }^{19}$ As a check on the specificity of the assay, serum samples were collected from five normal infants at seven weeks postpartum with no history of respiratory syncytial virus infection. All five possessed serum IgG antibodies to both glycoproteins ranging in titre from 2.4 to 3.0 $\log _{10}$ but none possessed detectable IgM antibodies. Although there was evidence of rheumatoid factor in 48 of the 86 samples from infected infants tested, in only five were levels as high as half of the specific antibody titre. These samples were omitted from the analysis. The $\log$ of the remaining IgM antibody titres to both $F$ and $G$ glycoproteins was normally distributed. No differences in IgM response to the two proteins were discernible.

IgG antibodies to the virus at the acute stage of infection may largely consist of maternal antibody acquired transplacentally that declines in titre with postpartum age. This conclusion is supported by the significant negative correlations between the age of the infant and the IgG antibody titres to both proteins at the acute stage of infection (table 2). A rise in antibody between acute and convalescent samples is a measure of the infant's own immune response. Significant positive correlations between age and

Table 2 Correlation coefficients between age and class specific antibody responses to respiratory syncytial virus glycoproteins

\begin{tabular}{llll}
\hline Antigen & \multicolumn{2}{l}{ Immunoglobulin class } \\
\cline { 2 - 3 } & IgG & $\frac{\text { IgM }}{\text { Acute }}$ \\
\cline { 2 - 4 } & Acute & Rise & $+0 \cdot 19$ \\
\hline F & $-0 \cdot 6^{* *}$ & $+0 \cdot 5^{* *}$ & $+0 \cdot 4^{*}$ \\
G & $-0 \cdot 4^{*}$ & & \\
\hline
\end{tabular}

${ }^{*}=\mathrm{p}<0 \cdot 05 ;{ }^{* *} \mathrm{p}=<0 \cdot 01$.

Table 1 Antibody responses to the $F$ and $G$ glycoproteins of respiratory syncytial virus

\begin{tabular}{|c|c|c|c|c|c|c|c|}
\hline \multirow{2}{*}{$\begin{array}{l}\text { Antibody } \\
\text { class }\end{array}$} & \multirow[t]{2}{*}{ Antigen } & \multicolumn{2}{|l|}{ Acute } & \multicolumn{2}{|l|}{ Convalescent } & \multirow{2}{*}{$\begin{array}{l}\text { No }(\%)^{*} \text { of } \\
\text { significant } \\
\text { responses }\end{array}$} & \multirow{2}{*}{$\begin{array}{l}\text { Mean } \\
\text { rise } \\
\left(\log _{10}\right)\end{array}$} \\
\hline & & $\begin{array}{l}\text { No }(\%) \\
\text { antibody } \\
\text { positive }\end{array}$ & $\begin{array}{l}\text { Mean }(S D) \\
\text { titre } \\
\left(\log _{(0)}\right)\end{array}$ & $\begin{array}{l}\text { No }(\%) \\
\text { antibody } \\
\text { positive }\end{array}$ & $\begin{array}{l}\text { Mean }(S D) \\
\text { titre } \\
\left(\log _{10}\right)\end{array}$ & & \\
\hline \multirow{2}{*}{$\operatorname{lgG}$} & $\mathbf{F}$ & $46 / 50(92)$ & $2.34(0.09)$ & $43 / 45(96)$ & $2.44(0.08)$ & $10 / 43(23)$ & $+0 \cdot 1$ \\
\hline & G & $40 / 54(74)$ & $2.13(0.08)$ & $31 / 45$ (69) & $2.04(0.09)$ & $5 / 44$ (11) & -0.09 \\
\hline \multirow{2}{*}{ IgM } & $\mathrm{F}$ & $42 / 51 \quad(82)$ & $1.31(0.01)$ & $36 / 40(90)$ & $1.33(0 \cdot 1)$ & $2 / 44(5)$ & +0.02 \\
\hline & G & $38 / 52$ (73) & $1 \cdot 16(0.06)$ & $45 / 45(100)$ & $1.35(0.08)$ & $3 / 44$ (7) & +0.19 \\
\hline
\end{tabular}

${ }^{*} \mathrm{~A}$ rise of equal to or greater than twice the standard deviation for repeated determinations of a single serum sample was taken as significant. Thus rises of $0 \cdot 6,0 \cdot 72,0 \cdot 72$, and $0 \cdot 74 \log _{10}$ or above were taken as significant for IgG anti-F, IgG anti-G, IgM anti-F, and IgM anti-G, respectively. 
1664 Toms, Webb, Milner, Milner, Routledge, Scott, Stokes, Swarbrick, and Taylor

Table 3 Correlation coefficients between titre of infectious virus and antibody response to respiratory syncytial virus glycoproteins

\begin{tabular}{llll}
\hline Antigen & \multicolumn{2}{l}{ Immunoglobulin class } & \\
\cline { 2 - 4 } & IgG & & \multicolumn{1}{l}{ IgM } \\
\cline { 2 - 4 } & Acute & Rise & Acute \\
\hline F & +0.14 & -0.30 & $-0.32(-0 \cdot 20)^{\dagger}$ \\
G & -0.02 & -0.04 & $-0.36^{*}(-0 \cdot 17)^{\dagger}$ \\
\hline
\end{tabular}

${ }^{*} \mathrm{p}<0 \cdot 05$.

+Figures in parentheses represent Spearman's rank correlation coefficient.

rises in antibody after infection suggest that older infants are able to respond more effectively. This conclusion is underlined by positive correlations between age and titres of IgM antibodies in acute sera. IgM antibodies do not cross the placenta and their presence in samples taken during the acute stage indicate an early response by the infant. The stronger correlation of age with the IgM response to the $\mathrm{G}$ protein may indicate that younger infants find it difficult to respond to this protein.

An increase in responsiveness with age may result from an inhibitory effect of antibody acquired transplacentally on the infants immune response. The ability of infants to make an IgM antibody response was not, however, correlated with acute serum titres of $\mathrm{IgG}$ antibody to either glycoprotein $(r=0.04$ in both cases).

There were no significant correlations between the severity of disease and titres of antibody in acute or convalescent samples to either glycoprotein or of either immunoglobulin class or rises in the titre of such antibodies after infection. There was, however, a general tendency for evidence of an immune response judged by rising titres of IgG antibody or high IgM antibody in samples taken during the acute phase to correlate with secretion of lower titres of infectious virus (table 3 ). Log infectious virus yields were not normally distributed, and this tendency was not significant when a non-parametric analysis was applied.

\section{Discussion}

A central question in this study is whether infants encountering respiratory syncytial virus for the first time at an early age develop a severe lower respiratory tract infection because of a selective deficiency of antibody to one of the virion glycoproteins as suggested by Hildreth et al. ${ }^{16}$ They reported lower titres of ELISA anti-G antibodies in serum samples from cord blood of infants who were infected with the virus in their first year compared with uninfected controls. These findings conflict with those of a previous study in which higher titres of antibody to the viral nucleoprotein but not the $\mathrm{G}$ glycoprotein were found in the serum samples of mothers whose babies subsequently escaped infection. ${ }^{15}$ It remains unclear whether the protective effect of maternal antibody measured at birth in these experiments is exerted directly upon the infant or indirectly by protecting the mother and thus reducing the risk of viral transmission to the infant in the first month of life. In this study we could find no correlation between titre of IgG antibody to either glycoprotein in serum samples taken during the acute phase, a measure of residual antibody that had been acquired transplacentally, and the clinical severity of infection. Neither was there any significant correlation between such antibody and virus titres in the respiratory tract. This suggests that antibodies acquired transplacentally have little direct influence on the course of infection in the infant, favouring the hypothesis that maternal antibodies protect the infant indirectly.

Ward et al observed that after infection anti-G, but not anti-F, responses were all but absent in younger infants. ${ }^{15}$ Subsequent studies employing ELISA 'against purified virion glycoproteins confirmed that both serum and mucosal IgG and IgA responses were poor in younger infants but there were no significant differences between anti-G and anti-F responses. ${ }^{14}$ In the present study we also observed poor IgG responses to both glycoproteins after infection and although responses to the $F$ protein were about twice as good as those to the G protein, this difference was not significant. Lower anti$G$ antibody titres might be expected if the infants were infected with a subgroup B virus, as the glycoproteins used in the assays were derived from a subgroup $A$ virus and there is a wider divergence of antigenicity between the $G$ than the $F$ proteins of the two subgroups. ${ }^{19}$ Unfortunately no means of subgrouping viruses was available when the specimens were collected.

As measurement of $\mathrm{IgG}$ responses is complicated by the presence of residual maternal antibody, the infants' immune responses to the two glycoproteins were further compared by measuring the infant IgM antibody response, the measurement of which is untrammelled by passively acquired IgG. Serum samples from over three quarters of the infants tested contained IgM antibodies on admission to hospital. This rate of response is consistent with that previously reported using virus infected cells as antigen, although in previous studies maximal responses have been detected a week after the onset of 
illness. ${ }^{1920}$ IgM antibody titres to both glycoproteins in samples taken during the acute phase were similar, and there was no evidence of a deficiency in antibody to the $G$ glycoprotein. Furthermore, no correlations between IgM antibody responses to either glycoprotein and the severity of illness were found. Serum IgM responses, but not IgG responses, were negatively correlated with virus in secretions. The correlation was weak and not significant when a non-parametric test was applied. This does, however, parallel the correlation between the local IgA response and cessation of virus shedding reported by McIntosh et $a l^{8}$ and confirms the importance of the early antibody responses in terminating virus secretion.

The infant antibody response was significantly greater in older infants, but improvement with age was more pronounced with IgG than with IgM. Murphy et al studied serum $\operatorname{IgA}$ responses and found that anti-F glycoprotein responses were related to age alone, while anti-G glycoprotein responses were determined by residual titres of maternal antibody that decayed with age. ${ }^{14}$ This does not seem to be so for the IgM response as, here, titres of IgM antibody to neither glycoprotein showed any significant negative correlation with maternal antibody in samples taken during the acute phase. This result is encouraging as it suggests that vaccination of young infants may be able to stimulate an IgM response despite the presence of high levels of maternal antibody in the serum. Such antibodies might offer some protection by restricting virus replication in the upper respiratory tract early in infection.

We thank Dr S McLachlan of the department of medicine, University of Newcastle upon Tyne for providing the affinity purificd human IgG, and Dr G Bird of the department of immunology, Newcastle General Hospital for the positive control samples for the assay for rheumatoid factor.

\section{References}

1 Parrot RH, Kim HW, Arrobio JO, et al. Epidemiology of respiratory syncytial virus infection in Washington, D.C. II. Infection and disease with respect to age, immunologic status, race and sex. Am J Epidemiol 1973;98:289-300.

2 Taylor G, Stott EJ, Bew M, Fernie BF, Cote PJ. Monoclonal antibodies protect against respiratory syncytial virus. Lancet 1983;ii:976.

${ }^{3}$ Hemming VG, Rodriguez W, Kim HW, et al. Intravenous immunoglobulin treatment of respiratory syncytial virus infections in infants and young children. Antimicrob Agents Chemother 1987:31:1882-6.

4 Neligan CA, Steiner HM, Gardner PS, McQuillin J. Respiratory syncytial virus infection of the newborn. Br Med J 1970;ii: 146.

5 Ogilvie MM, Vathenen AS, Radford M, Codd J, Key S. Mater- nal antibody and respiratory syncytial virus infection in infancy. J Med Virol 1981;7:263-71.

${ }^{6}$ Glezen WP, Paredes A, Allison JE, Taber, Frank AL. Risk of respiratory syncytial virus infection for infants from low-income families in relationship to age, sex, ethnic group, and maternal antibody level. J Pediatr 1981;98:708-15.

7 Bruhn FW, Yeager AS. Respiratory syncytial virus in early infancy-circulating antibody and the severity of infection. $\mathrm{Am} \mathrm{J}$ Dis Child 1977;131:145-8.

${ }^{8}$ McIntosh K, McQuillin J, Gardner PS. Cell-free and cell-bound antibody in nasal secretions from infants with respiratory syncytial virus infections. Infect Immun 1979;23:276-81.

9 Walsh EE, Brandriss MW, Schlesinger JJ. Purification and characterisation of the respiratory syncytial virus fusion protein. $J$ Gen Virol 1985;66:409-15.

10 Levine S, Klaiber-Franco R, Paradiso PR. Demonstration that glycoprotein $\mathrm{G}$ is the attachment protein of respiratory syncytial virus. J Gen Virol 1987;68:2521-4.

1 Routledge EG, Willcocks MM, Samson ACR, et al. The purification of four respiratory syncytial virus proteins and their evaluation as protective agents against experimental infection in BALB/c mice. J Gen Virol 1988;69:293-303.

12 Morgan LA, Routledge EG, Willcocks MM, Samson ACR, Scott R, Toms GL. Strain variation of respiratory syncytial virus. J Gen Virol 1987;68:2781-8.

${ }^{13}$ Hendry RM, Fernie BF, Anderson LJ, McIntosh K. Antigenic and epidemiologic analysis of distinct strains of respiratory syncytial virus from two successive community outbreaks (198385). In: Mahy B, Kolakofsky D, eds. The biology of negative strand viruses. Amsterdam: Elsevier, 1987:397-403.

14 Murphy BR, Alling DW, Snyder MH, et al. Effect of age and pre-existing antibody on serum antibody response of infants and children to the $F$ and $G$ glycoproteins during respiratory syncytial virus infection. J Clin Microbiol 1986;24:894-8.

15 Ward KA, Lambden PR, Ogilvie MM, Watt PJ. Antibodies to respiratory syncytial virus polypeptides and their significance in human infection. J Gen Virol 1983;64:1867-76.

${ }^{16}$ Hildreth SW, Belshe RB, Paradiso PR, Smith DH. Correlation between respiratory syncytial virus (RSV) glycoprotein specific maternal antibodies and RSV disease of infants. Pediatr Res 1987;21:917.

17 Voller A, Bidwell D, Barlett A. Microplate enzyme immunoassay for the diagnosis of viral infection. In: Rose NR, Friedman $\mathrm{H}$, eds. Manual of clinical immunology. Washington: American Society for Microbiology, 1976:506-12.

${ }^{18}$ Nandapalan N, Routledge E, Toms GL. An enzyme linked immunosorbent assay for $\mathrm{IgG}$ and $\mathrm{IgA}$ antibodies to respiratory syncytial virus in low dilutions of human serum and secretions. J Med Virol 1984;14:285-94.

19 Johnson PR, Spriggs MK, Olmsted RA, Collins PL. The glycoprotein of human respiratory syncytial viruses of subgroups $A$ and $\mathrm{B}$ : extensive sequence divergence between antigenically related proteins. Proc Natl Acad Sci USA 1987;84:5625-9.

20 Welliver RC, Kaul TJ, Putman TI, Sun M, Riddlesberger RN, Ogra PL. The antibody response to primary and secondary infection with respiratory syncytial virus: kinetics of classspecific responses. J Pediatr 1980;96:809-13.

${ }^{21}$ Hornsleth A, Friis B, Grauballe PC, Krasilnikof A. Detection by ELISA of IgA and IgM antibodies in serum in primary lower respiratory syncytial virus infection. J Med Virol 1984;13:149-61

Correspondence to Dr GL Toms, Department of Virology, The Medical School, Framlington Place, Newcastle upon Tyne NE2 4HH.

Accepted 14 July 1989 